\title{
PETROGRAPHY OF LOW-GRADE METAMORPHIC ROCKS OF THE LESSER HIMALAYA FROM MALEKHU AREA, CENTRAL NEPAL
}

\author{
Rajendra Acharya ${ }^{1}$ and Kabiraj Paudyal ${ }^{2}$ \\ ${ }^{1}$ Department of Geology, Birendra Multiple Campus, Tribhuvan University, Chitwan,Nepal \\ ${ }^{2}$ Central Department of Geology, Tribhuvan University, Kirtipur, Kathmandu, Nepal
}

\begin{abstract}
Petrographic study was carried out in the rocks of the Nawakot Group from the Malekhu area. Representative samples from all the units were collected systematically. The area is occupied by low-grade metamorphic rocks of the Lesser Himalaya. The main lithology of this study area consists of phyllite, quartzite, metasandstone, dolomite, slate and metabasics. The main aim of this study was to distinguish the individual rock types based on the petrographic characteristics. Necessity of this type of study is felt because about each geological unit has similar type of rocks. In the case of complex geological setting due to faults and thrusts, distinction between the macroscopically similar rocks is possible only under the thin sections. Keeping this geological problem in mind, altogether 12 thin sections of representative rocks were prepared and studied for mineral paragenesis, texture, microscopic structures, deformation characteristics and metamorphic grade. Chlorite is found in all pelitic rocks as a metamorphic index mineral.
\end{abstract}

Key words: Lesser Himalaya, Nawakot Group, Malekhu area, petrography, chlorite-grade

\section{Introduction}

Present study area is a small part of the Lesser Himalaya in Malekhu which is about $70 \mathrm{~km}$ west of Kathmandu. The Lesser Himalaya is a fold-andthrust belt of the Himalaya with rugged topography. The Nawakot Group is an autochthonous succession. Petrography is the study of mineral composition and fabric of rocks in thin section. This involves the description and systematic classification of rocks by means of microscopic examination. The mineral assemblage, especially tiny crystals of index mineral which is very important for the pressure-temperature interpretation in metamorphic process may not be observed on hand sample in the case of low-grade rocks. For that petrography can be used as a major tool. There are many problems of correlation of the Lesser Himalayan rocks in central Nepal.

\footnotetext{
*Corresponding author: Kabiraj Paudyal

Central Department of Geology, Tribhuvan University,

Kirtipur, Kathmandu, Nepal

Email: paudyalkabiraj@yahoo.com

(Received: 2015 June 04 Accepted: 2015 Aug 08)
}

Due to the lack of fossil content, biostratigraphy is not possible everywhere; so total correlation is based on the lithostratigraphy. For correlation, stratigraphic succession should be studied in detail. Correct identification of rock is the most important. Only hand sample cannot identify the rock precisely. Petrography is one of the important methods to identify the rocks. Mostly rock types found in the area are slate, phyllite, meta-sandstone, quartzite, limestone \& dolomite almost in all formations but in varying proportions and compositions. Not only for correlating and identifying the rocks, can petrography be used for detecting the opaques and magnetic minerals. Micro-structures developed in rocks help to assess the $\mathrm{P} / \mathrm{T}$ condition during metamorphism in some extent. The main problem of the Lesser Himalayan units is that there are similar type of rocks in many formations as separated out by some marker beds. Without study of total succession, it is hard to separate out the individual lithology under hand observation. For example, phyllite taken from the Kunchha Formation, Dandagaon Formation, Nourpul Formation and Robang Formation look like 
similar under hand sample. Similarly, for example, both the Fagfog Quartzite and the Purebesi Quartzite consist of dominantly quartzite, which are difficult to distinguish in hand samples, but in thin section we can clearly identify based on some microscopic minerals, unique textures and structures.

The study area is very significant for geologist as it is considered a reference section for the low-grade metasedimentary rocks of the Lesser Himalaya. Many geo-scientists worked in the area but detailed petrographical study was still lacking.

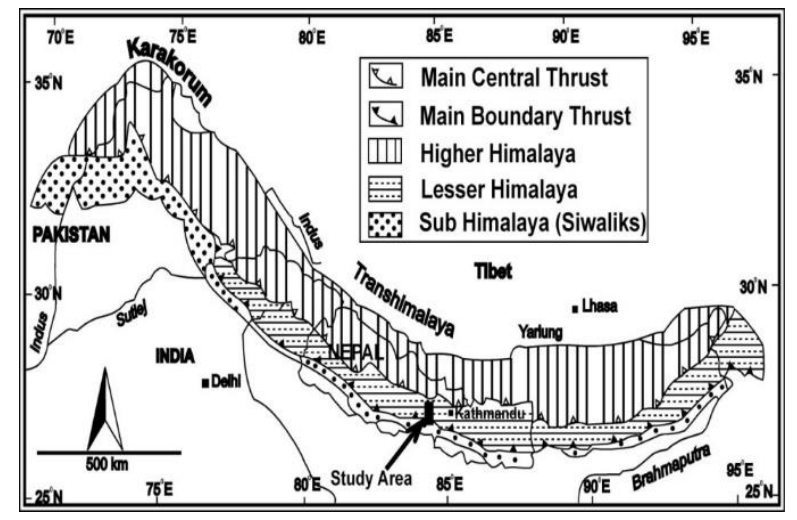

Fig 1 Litho-tectonic division of the Himalaya showing the present study location (modified after Gansser, 1964)

\section{Tectonic Setting}

The Himalaya is formed by collision of Indian and Eurasian plates in Middle Eocene (Le Fort, 1975). Nepal Himalaya is divided into four major tectonic zones from south to North: i) Sub-Himalaya (Siwalik), ii) Lesser Himalaya, iii) Higher Himalaya, and Tethys Himalaya (Gansser, 1964), Fig1. Present study area is a small part of the Lesser Himalaya in central Nepal. Several geo-scientists have studied the section in many aspects of geology (Stocklin and Bhattarai, 1977; Stocklin, 1980; Sah, 1999; Sah 2007; Rai, 2011; Pudashaini, 2014 and Paudyal and Paudel, 2011, 2012, 2013).

\section{Methodology}

The hand samples were collected in road and river sections in the field. Then thin sections representing each geological unit were prepared and the mineral paragenesis was studied. For petrographic study, the representative rock samples were selected for preparing thin section and systematic study of thin section was done under petrographic microscope in Central Department of Geology. The minerals, especially index minerals and their metamorphim, micro structure, magnetic minerals were also studied thoroughly with the help of petrographic microscope.

\section{Result}

During the field observation, large number of hand samples were collected systematically representing all the lithological units and rock types. Some representative samples were taken for thin section. A brief petrological description of these samples in stratigraphical order is presented below. Location of these samples is shown in generalized columnar section prepared in this study (Fig. 2).

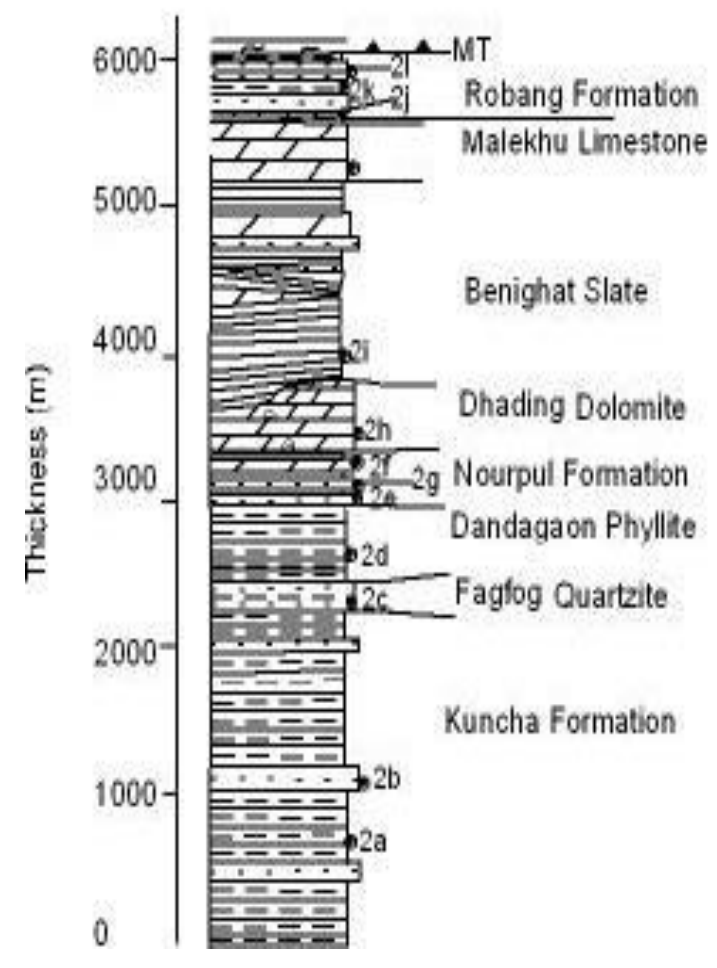

Fig 2 Generalized columnar section showing all the units observed in the Malekhu area along with sample location.

Lesser Himalayan rocks of the Nawakot Group are well exposed in the Malekhu section. The rock types of the this Nawakot Group include phyllite and 
meta-saandstone (the Kunchha Formation), quartzite (Fagfog Quartzite), phyllite (Dandagaon Phyllite), quartzite, phyllite, shale, meta-sandstone and dolomite (Nourpul Formation including its members Purebensi Quartzite and Labdi Khola Member), dolomite (Dhading Dolomite), black slate (Benighat Slate), dolomite (Malekhu Formation) and amphibolite, phyllite, quartzite (Robang Formation).

\section{Kunchha Formation}

Kuncha Formation mainly consists of monotonous, flysch-like alteration of phyllite, quartzite and metasandstones in varying proportions. Some phyllites are gritty and others pelitic and crenulated in nature. The petrographic description is given below.

\section{Phyllite}

This sample of phyllite was taken from the left bank of Thopal khola, at Kali Daha. The Phyllite was grey, fine-grained, crenulated and moderately weathered. Under petrographic microscope, it contains mineral assemblage of quartz +chlorite + plagioclase. The tentative modal composition is visually estimated as chiorite $\approx 70 \%$, quartz $\approx 17 \%$, plagioclase $\approx 10 \%$ and opaque and unidentified $\approx$ $3 \%$. The minerals are fine grained, (average size of qtz: $0.1 \mathrm{~mm}$, plagioclase is $0.15 \mathrm{~mm}$ and chlorite = $0.20 \mathrm{~mm}$ ) (Fig 2a). Quartz is anheldral whereas feldspar (plagioclase) is subhedral to anhedral. Chlorite is greenish colored and elongated. One set foliation is well defined by preferred orientation of chlorite.

\section{Metasandstone}

This sample of metasandstone was taken from the left bank of Thoppal khola, at Kali Daha. The metasandstone was grey, fine-grained and moderately weathered. Under petrographic microscope, it contains mineral assemblage of quartz + sericite + plagioclase. The tentative modal composition is visually estimated as sericite+muscovite $\approx 35 \%$, quartz $\approx 60 \%$, plagioclase $\approx 5 \%$ and opaque and unidentified $\approx 7 \%$. The minerals are fine grained, (average size of qtz: $0.1 \mathrm{~mm}$, plagioclase is $0.15 \mathrm{~mm}$ and chlorite $=0.20$ $\mathrm{mm}$ ) (Fig 2b). Quartz is anheldral whereas feldspar (plagioclase) is subhedral to anhedral.

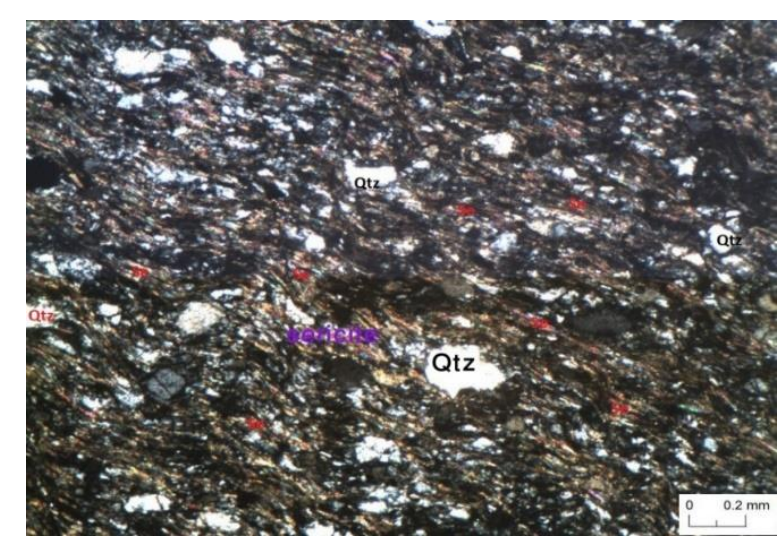

Fig 2a Photomicrograph of phyllite taken from the upper part of the Kunchha Formation.

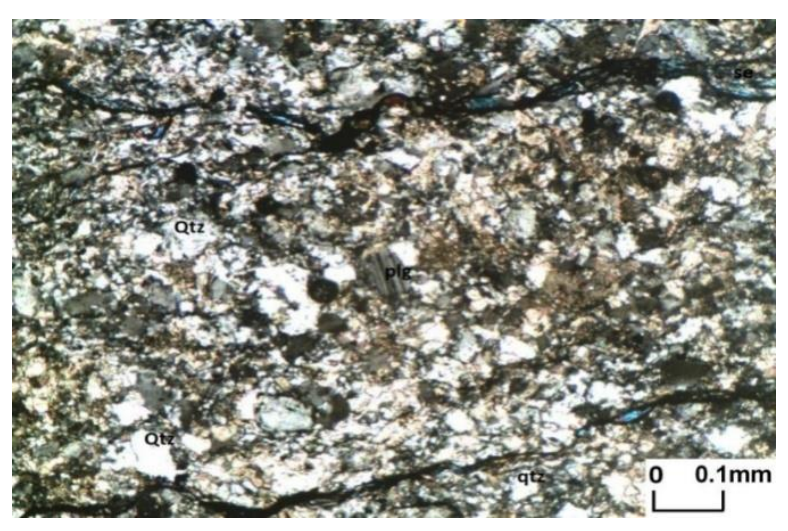

Fig $2 b$ Photomicrograph of metasandstone from the Kunchha Formation.

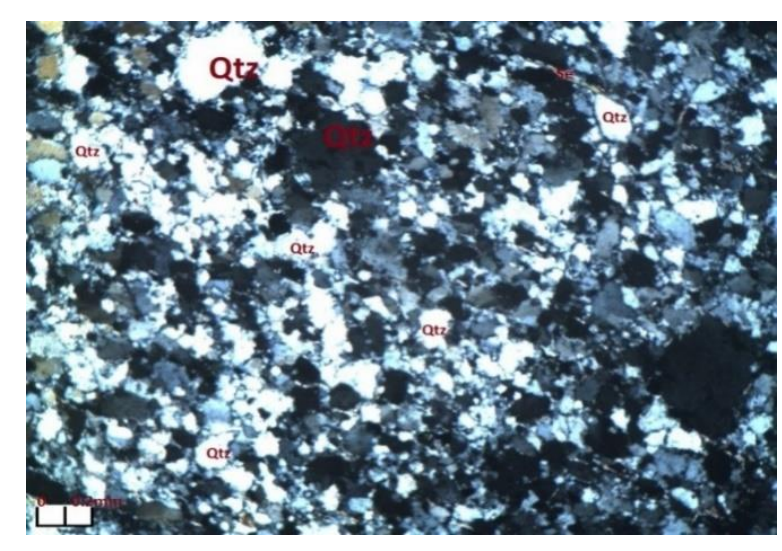

Fig 2c Photomicrograph of quartzite taken from the Fagfog Quartzite. 


\section{Fagfog Quartzite}

The Fagfog Quartzite consists of medium to coarsegrained white quartzite. The quartzite is fresh to faint weathering in outcrop. During the field work, numbers of representative samples were collected from this formation. Out of them one representative sample was selected for petrographic study.

\section{Quartzite}

This sample of quartzite was taken from MalekhuDhading road section. The quartzite was fresh to faintly weathered, fine to medium grained in outcrop. It contains mineral assemblage of quartz +sericite. The tentative modal composition is visually estimated as quartz $\approx 94 \%$, sericite $\approx 5 \%$ unidentified mineral $\approx 1 \%$. ( Fig $2 \mathrm{c}$ ). The mineral grains are fine, (average size of qtz: $0.2 \mathrm{~mm}$ ) anhedral, one set foliation is poorly defined by preferred orientation of sericite. Indented to suture contact is seen between quartz grains. Quartz grains shows excellent wavy extinction. Detrital tourmaline is also found.

\section{Dandagaon Phyllite}

In field the Dandagaon Phyllites consists of dark, blue-green, faint to moderate weathering phyllite with sub-ordinates of metasandstone and dolomite. During the field work, a number of representative samples were collected from this formation. Out of them one representative sample (black phyllite) was selected for thin section.

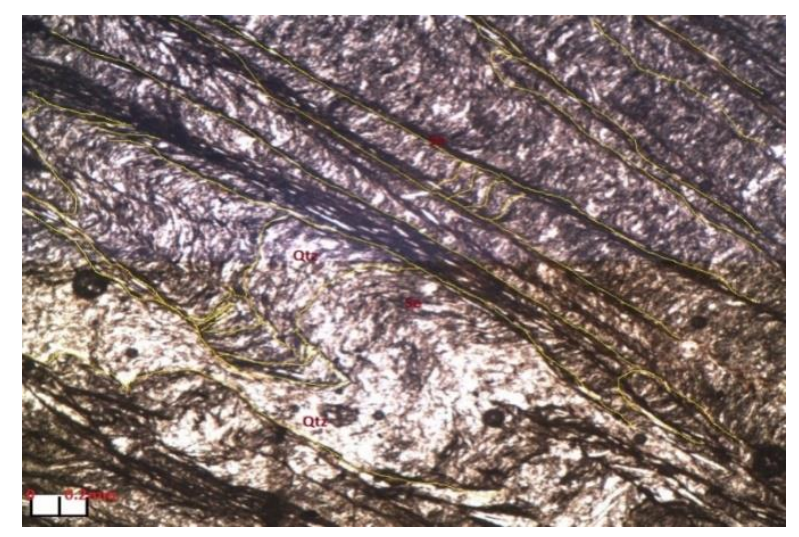

Fig 2d Photomicrograph of carbonaceous phyllite taken from the Dandagaon Phyllite.

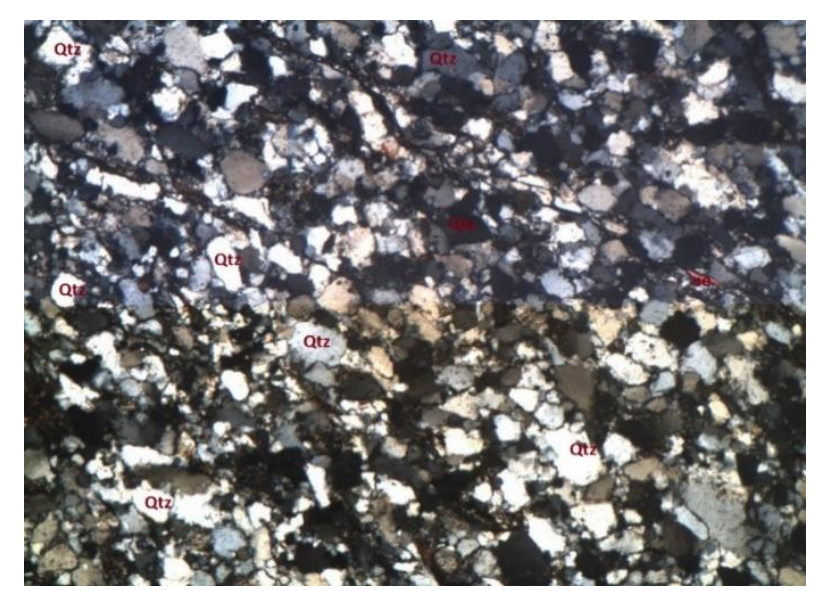

Fig 2e Photomicrograph of quartzite taken from the Nourpul Formation.

\section{Phyllite}

This sample of phyllite was taken from Malekhu Dhading road section. It contains mineral assemblage of quartz + sericite. The tentative modal composition is visually estimated as quartz $\approx 35 \%$, sericite/ muscovite $\approx 18 \%$ carbonaceous mineral $\approx$ $43 \%$ and unidentified mineral $\approx 4 \%$. (Fig $2 \mathrm{~d}$ ). Two set foliation (one set distinct and one set poor) is defined by preferred orientation of sericite.

\section{Nourpul Formation}

\section{Quartzite}

The sample of quartzite was taken from Malekhu Dhading road section. In field the outcrop was dirty grey, fine grained and moderately weathered. It contains mineral assemblage of quartz +chlorite. The tentative modal composition is visually estimated as quartz $\approx 88 \%$, sericite/ chlorite $\approx 10 \%$ detrital tourmaline $\approx 1 \%$ and opaque mineral $\approx 1 \%$. (Fig. 2e). The mineral grains are fine grained, ( average size of qtz: $0.2 \mathrm{~mm}$ ) anhedral. One set foliation is defined by elongated micaceous minerals.

\section{Metasandstone}

The sample of quartzite was taken from Malekhu Dhading road section. In field the outcrop was dirty grey, fine- to medoum-grained and moderately weathered. It contains mineral assemblage of quartz + muscovite + biotote. The tentative modal 
composition is visually estimated as quartz $\approx 60 \%$, muscovite +biotite $\approx 37 \%$ and unidentified mineral $\approx 3 \%$. (Fig $2 \mathrm{f}$ ). The mineral grains are fine grained, ( average size of qtz: $0.2 \mathrm{~mm}$ ) anhedral. One set foliation is defined by elongated micaceous minerals.

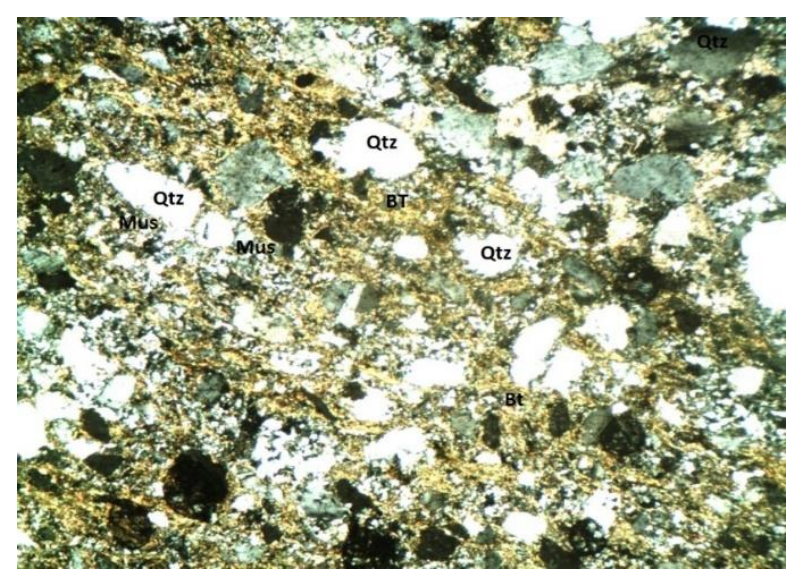

Fig $2 \mathrm{f}$ Photomicrograph of metasandstone collected from the Nourpul Formation. calcite $=20 \%$, quartz $\approx 5 \%$ and sericite $\approx 5 \%$. The size of quartz, calcite, and sericite are almost equal about to $0.3 \mathrm{~mm}$. Foliation is marked by platy minerals and elongated grains of quartz and calcite (Fig2h). Most of the minerals are subhedral to anhedral with some euhedral calcite crystals.

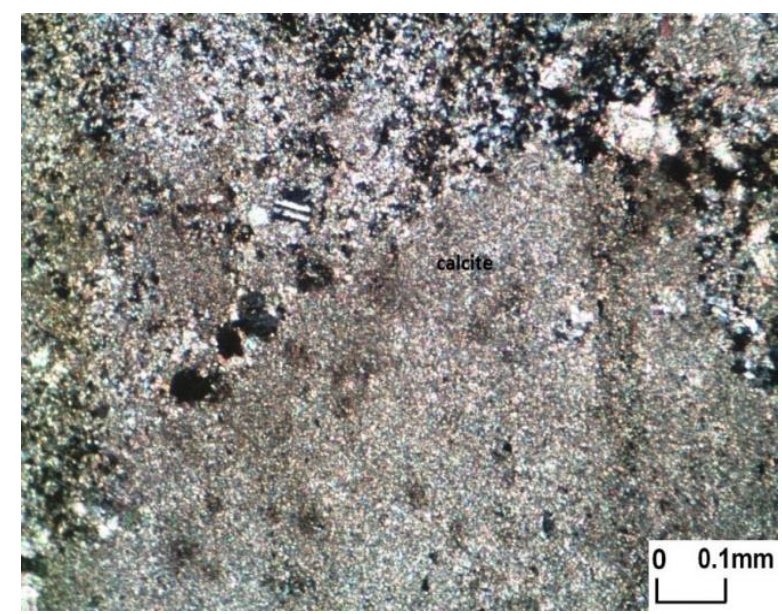

Fig $2 \mathrm{~g}$ Photomicrograph of dolomite from the Nourpul Formation.

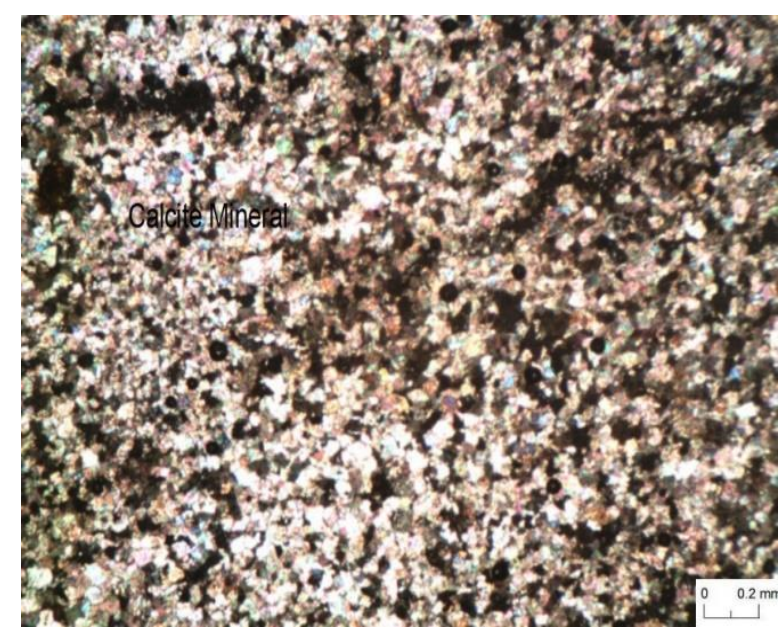

Fig 2h Photomicrograph of fine-grained dolomite taken from the Dhading Dolomite.

\section{Benighat Slate}

\section{Slate}

The sample was taken from Malekhu Dhading road section. The rock is black and moderately weathered in outcrop. It predominantly consist of dark mineral. The equilibrium mineral assemblage is quartz + 
chlorite + carbon. The visual modal composition is estimated as quartz $\approx 30 \%$, chlorite $\approx 5 \%$ and carbonaceous material $\approx 65 \%$. The maximum size of quartz is $0.2 \mathrm{~mm}$, whereas chlorite is very fine grained. One set of foliation is defined by the orientation of mica and quartz (Fig 2i).

\section{Robang Formation}

Among various samples from Robang Formations like quartzite, phyllite and metabasite, only one sample of metabasite was prepared for thin section.

\section{Metabasite}

This sample of metabasite was taken from Robang Formation of Malekhu section at left flank of Malekhu Khola. The outcrop was faintly weathered, fine to medium-grained, massive in outcrop. Under petrographic microscope, it contains mineral assemblage of amphibole+ plagioclase+ quartz. The tentative modal composition is visually estimated as amphibole (hornblende) $\approx 56 \%$, Plagioclase $\approx 23 \%$, quartz $\approx 10 \%$, sericite $\approx 6 \%$, opaque mineral $\approx 1 \%$. And unidentified mineral $\approx 4 \%$. The mineral grains are fine to medium grained, (maximum size of $\mathrm{Hbl}$ : $1.5 \mathrm{~mm}$, plagioclase: $0.9 \mathrm{~mm}$ qtz: $0.9 \mathrm{~mm}$ and average size of $\mathrm{Hbl}: 1 \mathrm{~mm}$, plagioclase: $0.5 \mathrm{~mm}$, qtz: $0.2 \mathrm{~mm}$, ). The hornblende contains two set cleavage at $120^{\circ}$ and plagioclase shows strong polysynthetic twinning. Nematoblastic texture (parallel prismatic) was seen (Fig 2j).

\section{Phyllite}

This sample of phyllite was taken from the left bank of Malekhu khola. The Phyllite was greenish grey, fine-grained, and moderately weathered. Under petrographic microscope, it contains mineral assemblage of quartz +chlorite +sericite. The tentative modal composition is visually estimated as chiorite $\approx 45 \%$, quartz $\approx 40 \%$, sericite/muscovite $\approx$ $15 \%$ and opaque and unidentified $\approx 3 \%$. The minerals are fine-grained, (average size of qtz: 0.1 $\mathrm{mm}$, and chlorite $=0.20 \mathrm{~mm}$ ) (Fig 2k). Quartz is anheldral whereas feldspar is subhedral. Chlorite is greenish colored and elongated. One set foliation is well defined by preferred orientation of chlorite and sericite.

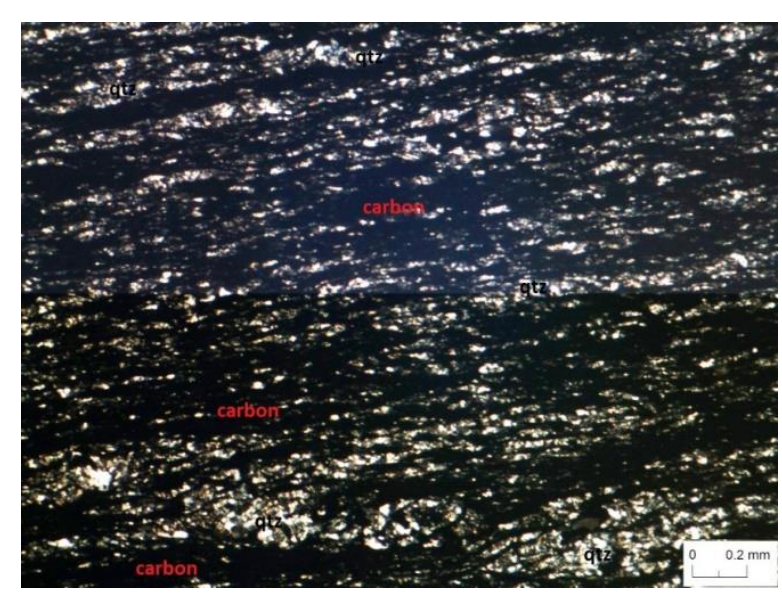

Fig 2i Photomicrograph of carbonaceous slate taken from the Benighat Slate.

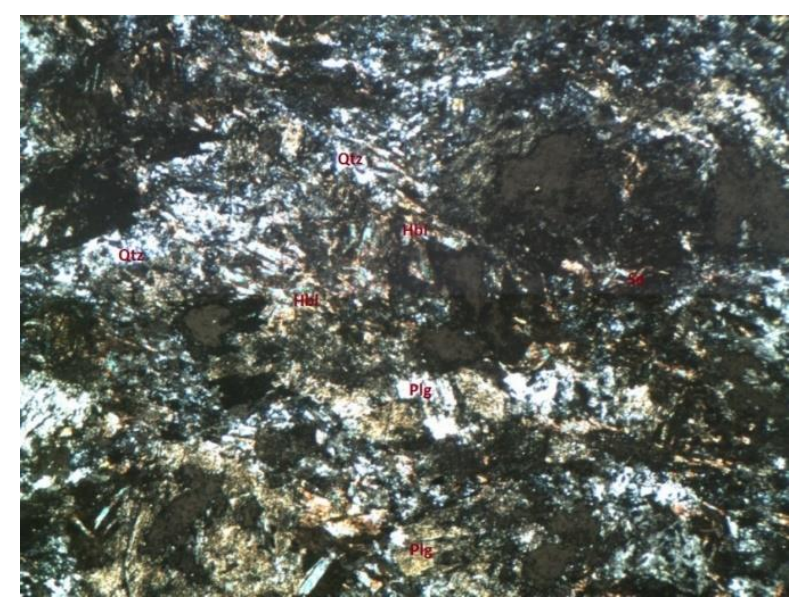

Fig 2j Photomicrograph of amphibolite from the lower part of the Robang Formation along the Malekhu Khola.

\section{Quartzite}

This sample of quartzite was taken from Malekhu khola section of Dunga Quartzite member of the Robang Formation. The quartzite was faintly weathered, thin to thick-bedded, fine to mediumgrained in outcrop. It contains mineral assemblage of quartz +sericite. The tentative modal composition is visually estimated as quartz $\approx 95 \%$, sericite $\approx 4 \%$ and unidentified mineral $\approx 1 \%$.( Fig. 21 ) The mineral grains are fine-grained, (average size of qtz: $0.4 \mathrm{~mm}$ ) and clearly anhedral. One set of foliation is poorly defined by preferred orientation of sericite. Indented to suture contact is seen between quartz grains. Quartz grains also show excellent wavy extinction. 


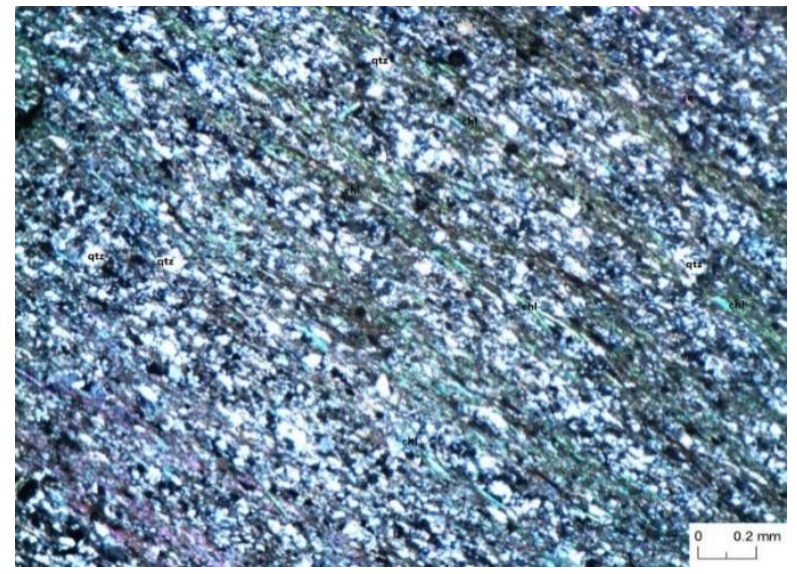

Fig 2k Photomicrograph of phyllite taken from the Robang Formation.

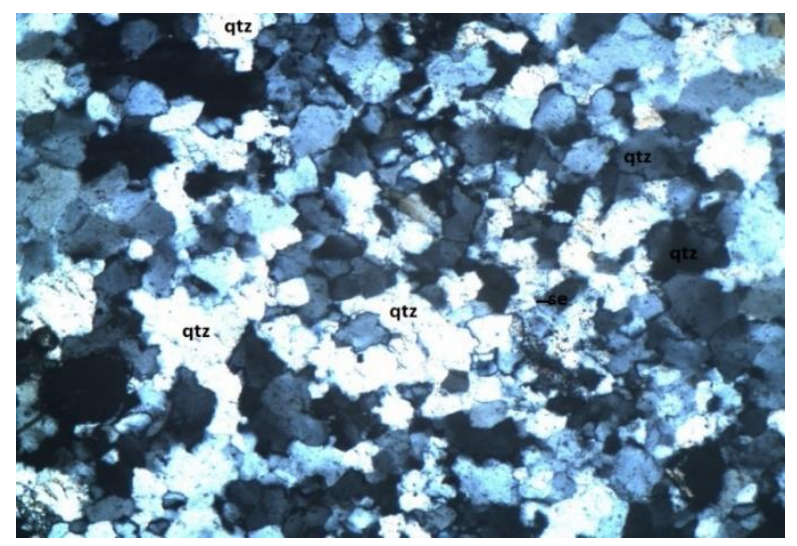

Fig 21 Photomicrograph of quartzite taken from the Robang Formation.

\section{Discussion}

During the field study, no any sign of unconformity is found between the Dhading Dolomite and the Benighat Slate as mentioned by Stöcklin and Bhattarai (1977) and Stöcklin (1980). Therefore, all the rock succession is considered under the Nawakot Group as proposed by the Paudyal and Paudel (2014).

From the petrographic study, the rocks of the entire succession are found low grade metamorphic rocks. Presence of crystallized grains of chlorite and sericite clearly indicates its low grade of metamorphism. The most of the rocks are of sedimentary origin. It is indicated by the relict beddings as well as abundant detrital mica and quartz in rocks. Deformation of rocks is found increasing from the older stratigraphic unit to the younger units. This type of deformation is related to the burial load in the rocks. It is evident in the rocks that the qauartz grain deformation and recrystallization have increased from the Kunchha Formation to the Robang Formation. It is found that the quartz grain boundary in the younger units is straight while in the lower units is somewhat indented to suture. However, in the quartzite of the Dunga Formation is suture, it could be due to the presence of the Mahabharat Thrust (MT) that brings the metamorphic crystalline rocks (succession of the Bhimphedi Group) over this unit. When we view the mineralogical composition in macroscopically similar type of rocks. There are some remarkable differences. For example, the quartz form the Fagfog Quartzite is less micaceous than the quartzite from the Dunga Quartzite. Similarly, the quatzite from the Nourpul Formation (Purebensi Quartzite member) has quartz with straight contact as most of them represent as a detrital grains in contrast to the quartzite from the Fagfog Quartzite where the quartz grains are well crystalline with indented contact. Some quartz grains in the Fagfog Quartzite show polygonization features as well. It is difficult to distinguish the phyllite taken from the different rock units merely based on the mineralogical composition and deformation characteristics only. There is significat metabasite in the Robang Formation showing its structure as a sill. Its mineralical assemblage shows its origin as from the basalt or dolerite. From the present study some microfabrics are seen such as, crenulation cleavage and micro folds in the phyllite of Kunchha Formation and the Dandagaon Phyllite. The Benighat Slate consists of large amount of carbonaceous material. The source of this carbonaceous matter is still a quationalble among the geo-scientists.

\section{Conclusion}

After petrographic study of rocks from Nawakot Group in Malekhu area, following conclusions can be drawn :

1. All rock types except one metabasite of the Nawakot Group belong to the sedimentary origin as indicated by their sedimentary relict features like bedding, detrital mineral composition and textures.

2. Metabasic rock (e.g. amphibolite) observed in the Robang Formation shows sill type intrusion. 
Its protolith can be interpreted as basalt or dolerite as indicated by its mineral composition.

3. Whole succession of the Nawakot Group belongs to the chlorite-grade of metamorphism.

4. Deformation on the rocks decreases slowly while moving to the stratigraphic up section.

5. Quartzites taken from the Kunchha Formation, Nourpul Formation and the Robang Formation are macroscopically similar; however, under polarizing microscope, these quartzites can be distinguished from each other based on petrographic characteristics. The quartzite taken from the Fagfog Quartzite shows strong deformation as indicated by the quartz grain boundaries and is well crystalline compared to other quartzites. Percentage of mica is abundant in the quartzites from the Robang Formation compared to other units.

6. Metasandstones from the Kunchha Formation is more crystalline and deformed as compared with the metasandstone from the Nourpul Formation.

7. Percentage of carbonaceous materials in phyllite and slate is increased in stratigraphic up position. The percentage of carbonaceous materials is more in the slates of the Benighat Slate compared to the Dandagaon Phyllite. Similarly, carbon content is more in the Dandagaon Phyllite as compared to the phyllite of the Kunchha Formation.

\section{Acknowledgement}

The first author is thankful to University Grant Commission (UGC) for M.Sc. dissertation grant. We are grateful to Central Department of Geology, Tribhuvan University for providing the laboratory facilities. The authors would like to thank Prof. Lalu Paudel, Head of the Central Department of Geology for the valuable suggestions in the first draft manuscript. We also would like to thank unknown reviewers for their critical review for the improvement of this manuscript.

\section{References}

[1] Gansser, A. (1964). Geology of the Himalayas. Interscience Publisher, London, 289p.
[2] Paudyal, K.R., and Paudel, L.P., 2011, Geological setting and lithostratigraphy of the Lesser Himalaya in the Mugling-Banspani area, central Nepal, Jour.Nepal Geol.Soc.,v.42, pp.51-63.

[3] Paudyal, K.R., and Paudel, L.P., 2012, Geological setting and lithostratigraphy of Bandipur-Gondrang area of Lesser Himalaya, central Nepal, Bull. Dept. of Geol., v. 15 , pp. 49-62.

[4] Paudyal, K. R. and Paudel, L. P. (2013). Geological study and root zone interpretation of the Kahun Klippe, Tanahun, and central Nepal. Himalayan Geology, v. 34(2), pp. 93-106.

[5] Paudyal, K. R., 2014. Geological and Petrological evolution of the Lesser Himalaya between Mugling and Damauli, central Nepal. PhD thesis, submitted to the Central Department of Geology, Institute of Science and Technology, Tribhuvan University, available in Central Library, Kirtipur, p.226.

[6] Pudashaini, R. (2014). Geology of Malekhu area and its comparison with the geology of Mugling-Narayangar area, central Nepal. M.Sc. dissertation, Central Department of Geology, Tribhuvan University, Kirtipur, p-147.

[7] Rai, S. (2011). Lithostratigraphy of the Nawakot Complex (Lesser Himalayan sequence) from Malekhu area (south-west) to Syabrubensi area (north-east) along the Trishuli River, central Nepal Himalaya. Journal of Nepal Geological Society, v. 42, pp. 65-74.

[8] Sah, R. B. (1999). Current understandings and existing problems on stratigraphy of Nepal Himalaya. Journal of SAN, v. 1, pp. 1-29.

[9] Sah, R. B. (2007). Correlation of Precambrian metasedimentary rock units of Nepal Lesser Himalaya. Journal of Stratigraphic Association of Nepal, v. 6, pp. 1120.

[10] Stöcklin, J. (1980). Geology of Nepal and its regional frame. Journal of Geological Society of London, v. 137, pp. 1-34.

[11] Stőcklin, J; Bhattarai, K. D. (1977). Geology of Kathmandu Area and Central Mahabharat Range Nepal. Department of Mines and Geology Kathmandu, Nepal, $86 \mathrm{p}$. 